\title{
A Persuasive in the Management of Indralupta (Alopecia areata) with Ayurvedic approach
}

\author{
Case Report
}

\section{Rani Manju1, Agarwal Riju², Gupta Kumar Prashant², Dhiman KS ${ }^{4}$}

\author{
1,2. Associate Professor, Chaudhary Brahm Prakash Ayurved Charak Sansthan, GGSIPU, New Delhi. \\ 3. Associate Professor, Shri NPA Govt Ayurved College, Raipur, Chhattisgarh. \\ 4. Director General, CCRAS, Janak Puri, New Delhi.
}

\begin{abstract}
The aim of the case study is to evaluate the efficacy of Leech therapy along with ayurvedic treatment in Alopecia areata (Indralupta). It is prospective interventional case report on alopecia areata treated with leech therapy and ayurvedic formulations. Using a subjective evaluation, an improvement in growth of hair on bald patches over scalp region was observed. An 18-year-old female patient, resident of Delhi, presented with complaints of two bald patches (right parietal \& vertex) over the scalp without any secondary changes. With these complaints, the patient visited Shalya Tantra, Outpatient department (OPD No 16) at Chaudhary Brahm Prakash Ayurved Charak Sansthan, New Delhi. She took treatment for six weeks and got complete remission in her symptoms. Line of treatment adopted was tridosha shamaka, rakta-shodhaka and raktamokashana (Leech application). Leech therapy supplemented with ayurvedic formulations have definite role in Alopecia Areata (Indralupta) especially of recent origin. A case series or pilot study may further strengthen above case report and open new treatment arena for such cases. This case report can also be used to formulate hypothesis for management of baldness from an ayurvedic perspective.
\end{abstract}

Key Words: Alopecia areata, Ayurveda, Ayurvedic treatment, Indralupta, Leech therapy, Shalya Tantra, Baldness.

\section{Introduction}

Alopecia areata (1) is a common form of baldness in which sudden loss of hair can be observed from scalp in patches. Loss of hair may involve entire scalp region (Alopecia areata totalis) or entire body surface (Alopecia areata universalis) and in severe cases, loss can be permanent. The term alopecia areata was coined by Sanvages in 1760 and described by Comelius celsus, (2) non- inflammatory type of alopecia accounts for approximately $25 \%$ of all the cases (3) and prevalence of alopecia areata in general population is estimated at $0.1-0.2 \%$. Although both the sexes are equally affected; some researches show male predominance (4). Usually the onset occurs in early childhood. The youngest patient reported is 4 months old and oldest was in late 70's. Highest rate of prevalence to be was noted between $30-59$ yrs of age. Familial involvement is present in $8.7-20 \%$ of cases (5).

It is seen that the first episode usually resolves spontaneously (6), but if it persists; it can act as important prognostic factor to assess the severity of the

\section{* Corresponding Author:}

Agarwal Riju

Associate Professor, Shalakya Tantra

Chaudhary Brahm Prakash Ayurved Charak Sansthan,

GGSIPU,

New Delhi

Email Id: rijuagarwal@gmail.com disease (7). In alopecia areata, patches are smooth and normal skin colour, characteristic yellow dot pattern is often seen with micro exclamation of hairs (short, fractured hairs with proximal tapering).

Many hypothesis are proposed to ascertain the etiology of alopecia areata, but it is still an enigma. It is believed to be an autoimmune disease (8), triggered by various factors like stress, emotional trauma, hormonal changes, infectious agents. Alopecia areata is considered as hair follicle specific autoimmune disease in genetically susceptible individuals, triggered by various factors. The types of hair loss patterns are reticular, ophiasis (snake like) \& sisaipho (ophiasis inversus). Definitive cure or preventive treatment for alopecia areata has not been established yet. Available treatment used, is mainly for hair growth, have never been proven to change the disease activity.

This includes use of oral/parenteral/topical/ systemic or intralesional steroids, photochemo-therapy and topical immunotherapy (9). Hair pieces and hair additions can also be used as a camouflage to address the emotional problems caused by cosmetic concern of alopecia areata.

\section{Case Presentation}

An 18-year-old female patient, resident of Delhi was apparently well six months back (Feb. 2017), however gradually, while combing hairs, her mother noticed loss of hairs from 2 patches over the scalp region. Later on, there was increase in size of the patches. On enquiry it was told that the loss of hair was not associated with itching, discharges, redness, edema 
Rani Manju et.al., A persuasive in the management of Indralupta (Alopecia areata) with Ayurvedic approach

etc. No significant aggravating and relieving factors were observed. On examination it was observed that the patches are present over right parietal and vertex region of scalp. She took consultation with allopathic and homeopathic doctors, but no improvement was noticed. With above mentioned complaints patient visited Shalya tantra OPD No 16 of Chaudhary Brahm Prakash Ayurved Charak Sansthan, Khera Dabar, New Delhi for management.

\section{History of Past illness}

History of Jaundice in Jan. 2016. No H/o DM/ HTN/Koch's/Asthma/Fever/surgical intervention was present in the patient. In family history her Sister had Leucoderma X 5-10 years.

\section{Personal history}

Patient is vegetarian with normal appetite of 3 meals a day, leading an active life style, with no addiction, getting 9-10 hours of sound sleep. It was also told that patient was fully Immunized during childhood. No relevant history of allergies was found.

\section{Dashvidhpariksha}

- Prakriti-vatapittaj,

- Vikriti-prakritisamsamveta,

- Sara-Mamsa sara,

- Samhanana-madhyam,

- Praman- madhyam,

- Satmya-madhyam,

- Satwa-Madhyam,

- Ahar-madhyam,

- Vyayam-madhyam,

- Vaya-yuva,

\section{Asthtavidha pariksha}

- Nadi-78/min regular, full volume;

- Mutra - pale yellow, burning micturition, 4-5 times a day 1-2 times night,

- Mala- once a day fully evacuated,

- Jihwa- niram pink in color, no anatomical deformity, no lesions seen,

- Shabda-spashta (clear),

- Sparsha - smooth without swelling,

- Drik - no change in skin color: margins - irregular,

- Aakriti - circular and longitudinal.

\section{General examination}

General examination of the patient was within normal limit.

\section{Local examination of scalp}

Inspection: 2 bald patches, longitudinal $(2.5 \mathrm{~cm} \times 5 \mathrm{~cm}$ approx) \& circular ( $2 \mathrm{~cm}$ radius approx) with ill-defined margins were found on right parietal \& vertex (Figure $1,2)$ respectively over the scalp.

\section{Palpation}

There was no local rise in temperature, no tenderness/ induration.
Laboratory Investigations: $\mathrm{Hb}-12.8 \mathrm{gm} \%$, BT - 1 min $29 \mathrm{sec}, \mathrm{CT}-4$ min 2 sec., HIV 1 and 2-Negative, HbsAg- Negative.

Concurrent treatment: No concurrent treatment was continued during study. Optimum (2-3 weeks) washout period was adopted to wean off the left-out effects of previous medication.

\section{Nidana Panchak}

- Nidana: Faulty food habits: It was told that patient used to have junk food frequently due to active/busy lifestyle \& stress.

- Purvaroopa: Fall of hair

- Roopa: 2 patches of skin with loss of hair over the right parietal and vertex region of the scalp.

- Samprapti: Nidana sewana - Vata-Pitta dosha prakopa - rakta + kapha dooshit romakoopaavrodha - hairfall (10).

- Treatment: Optimum washout period for previous medicine was adopted. She was advised internal \& external therapies. External therapy consists of leech therapy (11) and local application of Bhringraja oil (16) followed by wet towel steam thrice a week. Internal therapy consists of Amalki Churna (12) $3 \mathrm{gm}$ BD, Brihat Manjisthadi Kwatha (13) $40 \mathrm{ml}$. BD, Saptamrita Lauha (14) $500 \mathrm{mg}$ BD, Samshamni Vati (15) 2 tab. BD (Twice daily). Total duration of treatment was 8 weeks (internal therapy) and Leech therapy (17) for 6 weeks under aseptic conditions. The date of initiation of Samshamana therapy was 21.07.17 and of Leech therapy was 28.07.2017.

\section{Outcome and follow up}

Gradual reduction in hair loss was noticed (Figure 3 to 6), Bald patches over scalp covered with minute hairs within 6 weeks and after 6 months normal hair growth was seen over patches (Figure $7 \& 8$ ). No further hair loss was observed, no new patches appeared.

\section{Discussion}

The cases of Alopecia areata are keep on increasing day by day because of the altered lifestyle. In clinical practice, we frequently encountered with such cases and now it is increasing in young subjects. Cosmetically hair are important part of personality and baldness produce lots of side effects e.g. lack of confidence, personality defects, inferiority complex. According to ayurvedic principles, vitiated Vata and Pitta are responsible for hair fall and vitiated Rakta and Kapha obstructs the channels of hair follicles (18). Closed follicles lead to stoppage of regeneration of new hairs, the condition known as Indralupta (hair fall in patches i.e. Alopecia areata), Khalitya or Ruhya (19). It can be ascertained that in cases of Indralupta, Tridosha along with Rakta are the main causative factors. Line of treatment for this condition is Snehana (Oleation), Swedana (Fomentation) followed by Raktamokashana (Blood letting) (20). 
Drugs used for oral therapy are mainly Tridosha shamaka, Rakta shodhaka and Rasayana in nature of action. Bhringraja (Eclipta alba) taila (Snehana) was topically used for head massage as it is a proven, potent hair revitalizer followed by wet towel steam (Swedana) which improves circulation and helps in opening of ducts of hair follicles. Along with Bhringraja it also contains Manjistha (Rubia cordifolia), daruharidra (Berberis aristate) $(21,22,23)$ which are potent antimicrobial drug. Brihat Manjishtadi kwath is indicated in Vata rakta, Raktashodhaka, Tvak vica and Kushtha. It is used as potent blood purifier contains Varun (Crateva nurvala)(24) which facilitates removal of toxins from the body. Amalki (Embelica officianalis) Churna, Samshamni Vati and Saptamrita Lauha are mainly used as Rasayana in action.

Rakta, being the vehicle to carry and transport absorbed nutrients, oxygen, metabolites etc from one place to another, so correction of any abnormality in the Rakta by taking it out (Blood-letting) effectively cures number of diseases. Raktamokashana in this case performed with leech application as it is described as best method to pacify the vitiated Pitta and Rakta. Leech sucks the blood and improves local blood circulation mainly by injecting histamine like substances that causes vasodilatation. After the evacuation of vitiated blood from the affected site, rechannelization of blood flow is stabilized. Many studies have confirmed that leeches have more than hundred bioactive substances in its saliva, which mainly have analgesic, anticoagulant and anti-inflammatory effects. This is the reason for selecting the combination of topical application, systemic medications and leech therapy for treating this particular case. The available treatment in modern medicine mainly based on steroid and minoxidil etc. which have their own side effects. Leech therapy works similar to minoxidil as it improves the local blood circulation along with its antiinflammatory action.

\section{Conclusion}

Leech therapy along with ayurvedic systemic therapy has a definite role in alopecia areata especially of recent origin.

A case series or pilot study should be conducted in the similar cases to validate the above case report which may treat many such cases.

This case report can also be used to generate hypothesis for management of baldness from an ayurvedic perspective.

\section{Reference}

1. Seetharam KA. Alopecia areata: An update. Indian J Dermatol Venereol Leprol 2013;79:563-75.

2. Sharma VK, Dawn G, Kumar B. Profile of alopecia areata in Northern India. Int $J$ Dermatol 1996;35:22-7.

3. McMichael AJ, Pearce DJ, Wasserman D, Camacho FT, Fleischer Jr AB, Feldman SR, et al. Alopecia in the United States: Outpatient utilization and common prescribing patterns. J Am AcadDermatol 2007;57:S49-51.

4. Tan E, Tay YK, Goh CL, Chin Giam Y. The pattern of alopecia areata in Singapore - A study of 219 Asians. Int J Dermatol 2002;41:748-53.

5. Muller SA, Winkelmann RK. Alopecia areata - An evaluation of 736 patients. Arch Dermatol 1963;88:290-7.

6. Pratt $\mathrm{CH}$, King LE, Messenger AG, Christiano AM, Sundberg JP. Alopecia areata. Nat Rev Dis Primers. 2017;3:17011. Published 2017 Mar 16. doi:10.1038/nrdp.2017.11

7. Wasserman D, Guzman-Sanchez DA, Scott K, McMichael A. Alopecia areata. Int J Dermatol 2007;46:121-31.

8. Barahmani N, Schabath MB, Duvic M. History of atopy or autoimmunity increases risk of alopecia areata. J Am AcadDermatol 2009;61:581-91.

9. Brzezińska-Wcisło L, Bergler-Czop B, WcisłoDziadecka D, Lis-Święty A. New aspects of the treatment of alopecia areata. Postepy Dermatol Alergol. 2014;31(4):262-5.

10. Brahmanand Tripathi, Madhav Nidanam, Kshudraroga Nidana, Ch. 55, Ver. 28-29, Varanasi: Chaukhambha Surbharti Prakashan; 1996. p.268.

11. Kumar Mahesh, Rani Manju, Leech therapy in Vicharchika (Eczema): Own Experience, PunarnaV,2016,Jan - Feb, Vol 4, issue 1, 01-06.

12. Anonymous, Ayurveda sarsangraha. Kolkata: Shri Baidyanath Ayurveda bhavan; Sanshamnivati, 2016.p.312.

13. Ambika Dutta Shastri, editor. Bhaisajya Rantnawali of Govind Das, Prameha Chikitsa Adhyaya, Ch.37, Ver.34, Reprint ed.Varanasi: Chaukhambha Prakashan; 2011. p.723.

14. Ambika Dutta Shastri, editor. Bhaisajya Rantnawali of Govind Das, Shula Roga Chikitsa Adhyaya, Ch.30, Ver.130-131, Reprint ed.Varanasi: Chaukhambha Prakashan; 2011. p.648.

15. Ambika Dutta Shastri, editor. Bhaisajya Rantnawali of Govind Das, Shula Roga Chikitsa Adhyaya, Ch.30, Ver.130-131, Reprint ed.Varanasi: Chaukhambha Prakashan; 2011. p.648.

16. Ambika Dutta Shastri, editor. Bhaisajya Rantnawali of Govind Das, Shula Roga Chikitsa Adhyaya, Ch.30, Ver.130-131, Reprint ed.Varanasi: Chaukhambha Prakashan; 2011. p.648.

17. Kumar Mahesh, Rani Manju, Natural water habitat is best for Leech farming: An observational study, WJPPS, Vo; 7, Issue 8, 2018:1037-1048.

18. Anant Ram Sharma, Hindi commentary on Sushruta Samhita, Vol. 1: Ch.13, Ver. 34-35, Varanasi: Chaukhambha Surbharti Prakashan; 2006. p.558.

19. Brahmanand Tripathi, Madhav Nidanam, Kshudraroga Nidana, Ch. 55, Ver. 28-29. Varanasi: Chaukhambha Surbharti Prakashan; 1996. p.270.

20. Ambika Dutta Shastri, Hindi commentary on Sushruta Samhita, Chi. S., Vol. 1, Ch. 20, Ver. 24, Varanasi: Chaukhambha Sanskrit Sansthan 1997 p.95.

21. Agarwal Riju, Rani Manju, Dhiman K.S. A clinical study on the effect of Rasanjana (extract of Berberis 
Rani Manju et.al., A persuasive in the management of Indralupta (Alopecia areata) with Ayurvedic approach

aristata) eye drops in treatment of Netra abhishyanda (infective conjunctivitis). Int. Res. J. Pharm. 2014; 5(3):198-202.

22. Dhiman KS, Awasthi Sanjeev, Agarwal Riju, Tanwar Manoj. Clinical trials on Rasanjana (Aq. Extract of Berberis Aristata roots) \& Honey eye drops in Netra-Abhishyanda (Infective Conjunctivitis). Journal of Research in Ayurveda and Sidha, 2011;32:15-30.
23. Gaur Amit, Agarwal Riju, Dhiman KS, Rani Manju, Pandey Ruchi. A Clinical study on efficacy of Indukanta Yoga \& Darvyadi Yoga in Tundikeri W.S.R. to Ac. Tonsillitis. Journal of Ayurveda \& Holistic Magazine, 2014;2:18-30.

24. Rani Manju, Agarwal Riju, Dhiman K S, Sijjoria K $\mathrm{K}$. Role of Varuna Guda in the management of Mutrashmari (Urolithiasis) and assessment with imaging techniques. Journal of Ayurveda and Holistic Medicine (JAHM): 2014; 2(2).p.27-37.

Table No. 1: Details of drug used for this study

\begin{tabular}{|c|c|c|c|c|}
\hline S.No. & $\begin{array}{l}\text { Name of the } \\
\text { drug }\end{array}$ & Ingredients & Dose & Dosage form \\
\hline 1 & $\begin{array}{l}\text { Brihat } \\
\text { Manjishthadi } \\
\text { Kwatha }\end{array}$ & $\begin{array}{l}\text { Manjistha, Musta, Kutaja, Guduchi, Kushtha, } \\
\text { Nagara, Sharangi, Kshudra, Kataka, Vidanga, } \\
\text { Chitraka, Trymana, Bhringraja, Patha, } \\
\text { Chandana, Varuna, Bakuchi, Shakhotaka, } \\
\text { Karanja etc. }\end{array}$ & $40 \mathrm{ml}$ orally & Decoction \\
\hline 2 & Bhringraja Oil & $\begin{array}{l}\text { Bhringraja, Manjishtha, Chandana, Bala, } \\
\text { Daruharidra, Priyangu, Parpaundrika, } \\
\text { Sarivaetc }\end{array}$ & $\begin{array}{l}3 \text { application per } \\
\text { week, } 1 \mathrm{hr} \text { before } \\
\text { head wash }\end{array}$ & $\begin{array}{l}\text { Exteranal } \\
\text { application, } \\
\text { Nasya, } \\
\text { Shirodhara }\end{array}$ \\
\hline 3 & Amalaki Powder & Powder of emblica officinalis & $5 \mathrm{gm} \mathrm{BD}$, orally & Powder \\
\hline 4 & Sanshamni Vati & Guduchirasakriya & $2 \mathrm{BD}$, orally & Tablet \\
\hline 5 & $\begin{array}{l}\text { Saptamrita } \\
\text { Lauha }\end{array}$ & $\begin{array}{l}\text { Madhuka, Amalaki, Vibhitaka, Haritaki, } \\
\text { Lauha Bhasma }\end{array}$ & $2 \mathrm{BD}$, orally & Tablet \\
\hline
\end{tabular}

Table No. 2: Timeline

Date

February 2017

March 2017

\begin{tabular}{|c|c|}
\hline & swelling/discoloration etc \\
\hline April - June 2017 & Tried various allopathic and homeopathic treatment but got no relief \\
\hline $\begin{array}{l}\text { First 2-3 weeks of } \\
\text { July }\end{array}$ & Wash Out Period \\
\hline 21.07.17 & $\begin{array}{l}\text { Patient started treatment at Shalya dept. of CBPACS. Patient was advised following } \\
\text { treatment: Brihat Manjisthadi decoction, Amalaki churna, Tab Saptamrita Lauha, } \\
\text { Sanshmani vati along with protein rich diet. Preliminary investigations for leech therapy } \\
\text { was done. Head steam with Bhringraja oil application thrice weekly was advised. }\end{array}$ \\
\hline 28.07 .17 & $1^{\text {st }}$ sitting of Leech therapy done, rest medications continue. \\
\hline 05.08 .17 & $\begin{array}{l}2^{\text {nd }} \text { sitting of leech application done. } \\
\text { Sparse vellus hair with brownish appearance visible over the bald patches. }\end{array}$ \\
\hline 12.08 .17 & $\begin{array}{l}3^{\text {rd }} \text { sitting of leech application done. } \\
\text { More vellus hair visible over the patches }\end{array}$ \\
\hline 19.08 .17 & $\begin{array}{l}4^{\text {th }} \text { sitting of leech application done. } \\
\text { Small blackish hairs visible. }\end{array}$ \\
\hline 26.08 .17 & $\begin{array}{l}5^{\text {th }} \text { sitting of leech application done. } \\
\text { Patches partially covered by thick black hairs. }\end{array}$ \\
\hline 02.09 .17 & $\begin{array}{l}6^{\text {th }} \text { sitting of leech application done. } \\
\text { Both Patches fully covered by thick hairs. }\end{array}$ \\
\hline Sep 2017 & Complete resolution. \\
\hline $\begin{array}{l}\text { Follow } \\
\text { Up }\end{array}$ & $\begin{array}{l}6 \text { months } \\
\text { No episode of Alopecia observed. }\end{array}$ \\
\hline
\end{tabular}


Figure $1 \& 2$ : Before Treatment
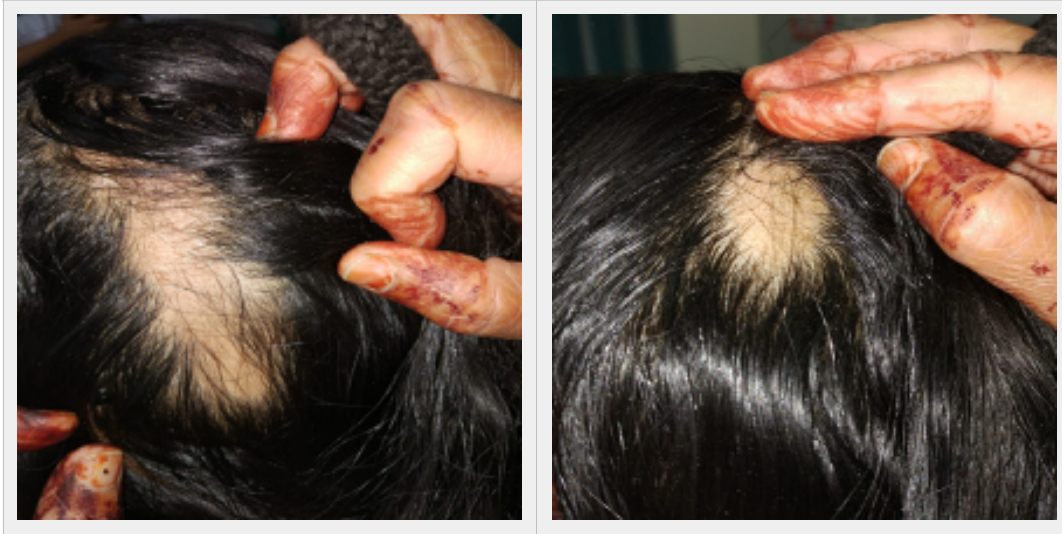

Figure $3 \& 4: 1^{\text {st }}$ Leech application
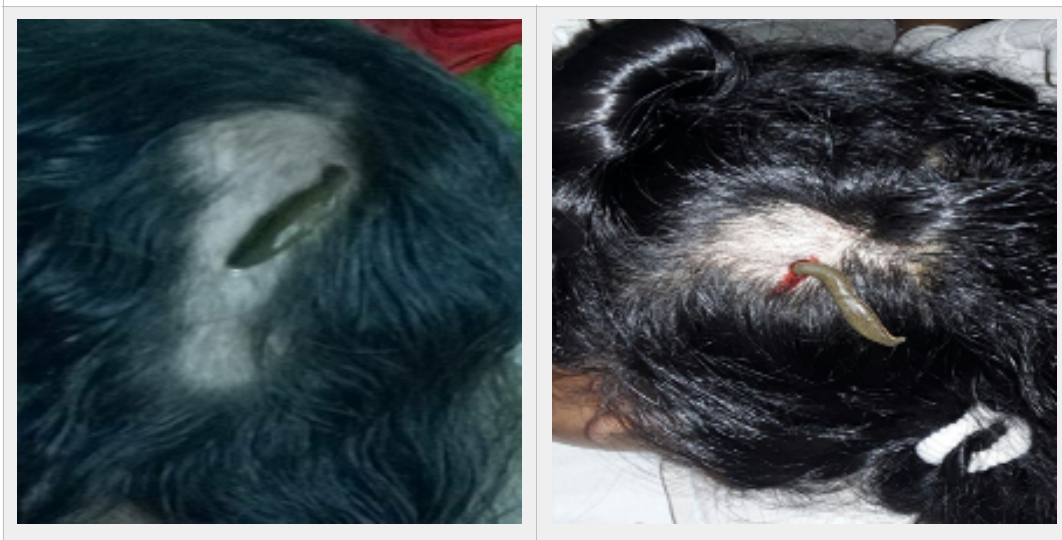

Figure $5 \& 6:$ after $4^{\text {th }}$ Leech application
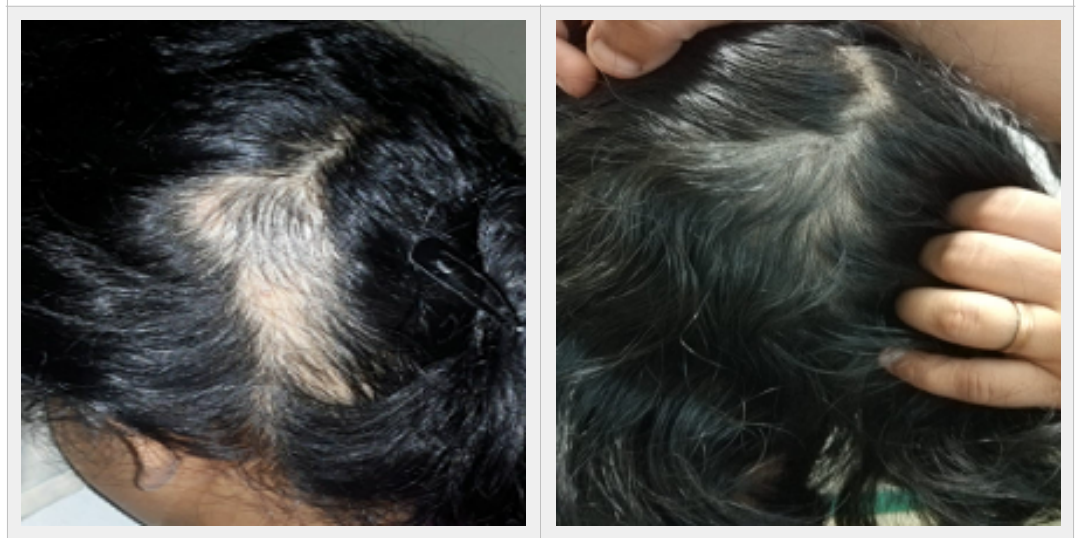

Figure 7 \& 8: Final Outcome

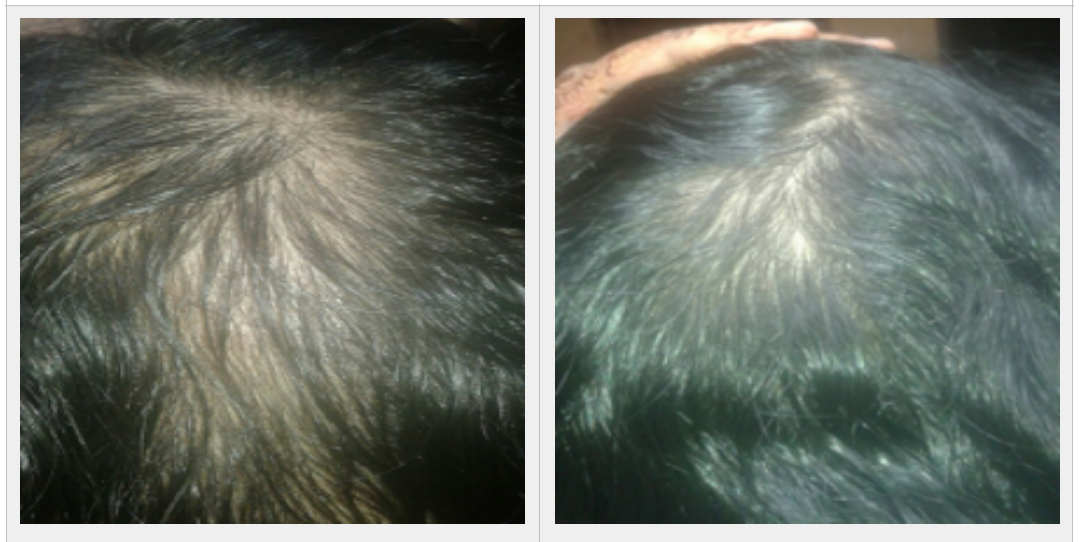

